\title{
Noninvasive microscopic imaging of sensory receptors in neuropathy
}

Figure In vivo reflectance confocal microscopy of Meissner corpuscles (MCs)
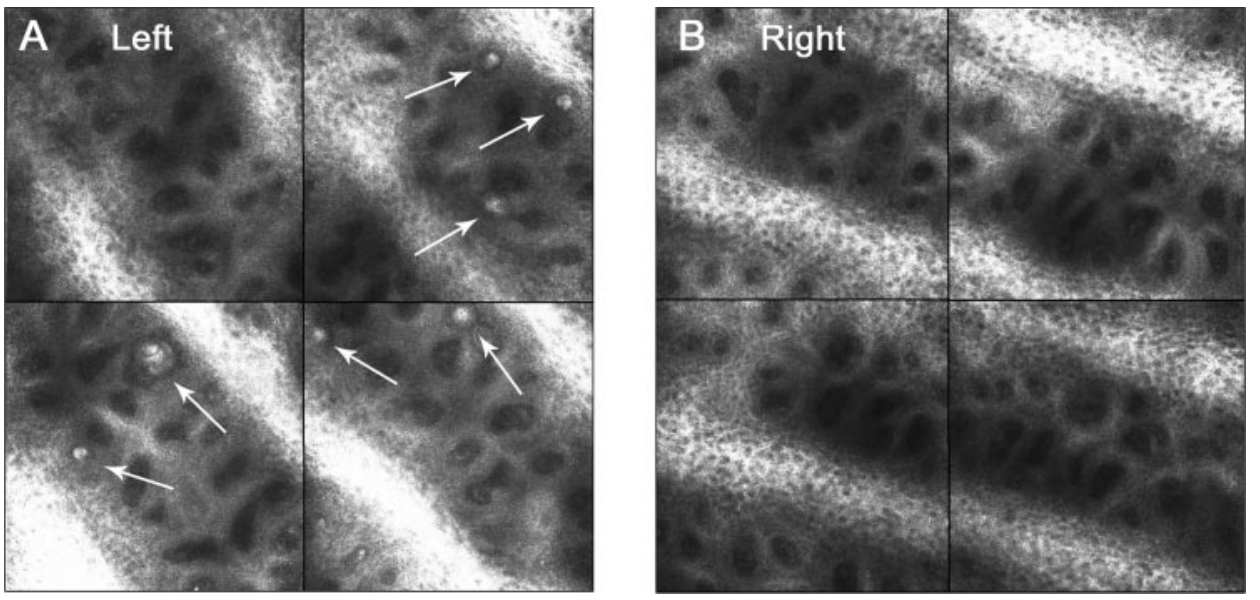

Reflectance confocal microscopy of MCs (arrows) of the left (A) and right (B) Vth digits demonstrated reduced MC density on the right, indicating axon loss. MC densities were $5.2 / \mathrm{mm}^{2}$ (left) and $1.2 / \mathrm{mm}^{2}$ (right) digit V. Left and right medial hand MC densities were $1.6 / \mathrm{mm}^{2}$ and $0.17 / \mathrm{mm}^{2}$, respectively.

A 53-year-old woman with small fiber neuropathy and right trigeminal neuropathy had numbness in the right hand (digits IV/V) for 2 months, with reduced sharp and vibration sensation and preserved strength. Nerve conduction studies (NCS) disclosed absent right fifth digit and dorsal ulnar cutaneous sensory potentials, with normal ulnar motor NCS. In vivo reflectance confocal microscopy $(\mathrm{RCM})^{1}$ was performed to assess skin innervation and distinguish sensory axon loss from demyelination/conduction deficits (figure). Markedly reduced Meissner corpuscle density indicated sensory axon loss, directing diagnostic evaluations away from sensory demyelinating neuropathies; her sensory neuropathy was likely related to Sjögren syndrome. In vivo RCM is painless, noninvasive, and may complement NCS for diagnosis, prognosis, and treatment. ${ }^{1}$

Nicholas E. Johnson, MD, David N. Herrmann, MBBCh, Rochester, $N Y$

Author contributions: Nicholas E. Johnson: drafting manuscript, design of project. David N. Herrmann: revision of manuscript, design of project.

Acknowledgment: Technical support provided by Michelle Ferguson, Janet Sowden, and Kai Bekar.

The authors report no disclosures relevant to the manuscript. Go to Neurology.org for full disclosures.

Correspondence \& reprint requests to Dr. Johnson: Nicholas_Johnson@urmc.rochester.edu

1. Herrmann DN, Boger JN, Jansen C, Alessi-Fox C. In vivo confocal microscopy of Meissner corpuscles as a measure of sensory neuropathy. Neurology 2007;69:2121-2127. 


\section{Neurology}

\section{Noninvasive microscopic imaging of sensory receptors in neuropathy \\ Nicholas E. Johnson and David N. Herrmann \\ Neurology 2012;78;1803 \\ DOI 10.1212/WNL.0b013e31825830d2}

This information is current as of May 28, 2012

\section{Updated Information \& Services}

References

Subspecialty Collections

Permissions \& Licensing

Reprints including high resolution figures, can be found at: http://n.neurology.org/content/78/22/1803.full

This article cites 1 articles, 1 of which you can access for free at: http://n.neurology.org/content/78/22/1803.full\#ref-list-1

This article, along with others on similar topics, appears in the following collection(s):

\section{EMG}

http://n.neurology.org/cgi/collection/emg

Peripheral neuropathy

http://n.neurology.org/cgi/collection/peripheral_neuropathy

Information about reproducing this article in parts (figures,tables) or in its entirety can be found online at:

http://www.neurology.org/about/about_the_journal\#permissions

Information about ordering reprints can be found online:

http://n.neurology.org/subscribers/advertise

Neurology ${ }^{\circledR}$ is the official journal of the American Academy of Neurology. Published continuously since 1951, it is now a weekly with 48 issues per year. Copyright Copyright @ 2012 by AAN Enterprises, Inc.. All rights reserved. Print ISSN: 0028-3878. Online ISSN: 1526-632X.

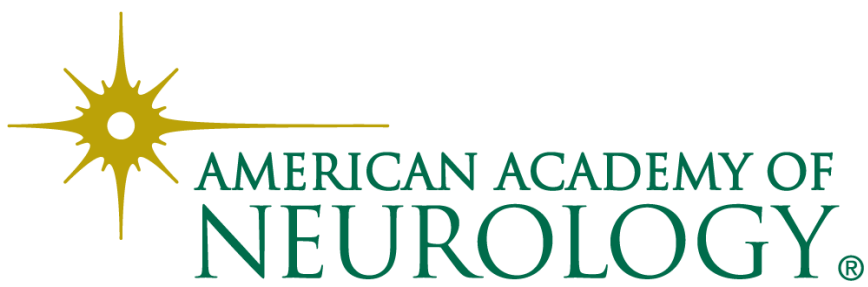

